\title{
G6PD (Dublin): chronic non-spherocytic haemolytic anaemia resulting from glucose-6-phosphate dehydrogenase deficiency in an Irish kindred
}

\author{
SHAUN R MCCANN, ANNE M SMITHWICK, IAN J TEMPERLEY, \\ AND KEITH TIPTON
}

From the Department of Haematology, Federated Dublin Voluntary Hospitals, and the Department of Biochemistry, Trinity College, Dublin, Ireland

SUMMARY A new variant of G6PD associated with chronic non-spherocytic haemolytic anaemia (CNSHA) in an Irish male is described. This variant is unique in that it has a normal electrophoretic mobility, Michaelis constant for G6P and NADP, and a normal pH optimum, together with a marked increase in utilisation of the substrate 2 deoxy glucose-6-phosphate. It is also relatively heat stable when compared with the normal (B) variant. These characteristics distinguish this variant from previously reported variants associated with CNSHA and we have called it G6PD Dublin.

Although over 100 genetic variants of glucose-6phosphate dehydrogenase (G6PD) have been reported, only three major clinical groups are well recognised. ${ }^{1}$ These are the 'Mediterranean' variety, the 'Negro' variety, and the 'sporadic' variety. Sporadic cases of G6PD deficiency associated with chronic non-spherocytic haemolytic anaemia (CNSHA) have been reported in Western Europe, but the disease is not listed as occurring in Ireland. ${ }^{2}$ This communication describes G6PD Dublin, a new variant discovered in an Irish male with CNSHA.

\section{Case report}

The proband, a 31-year-old male was admitted to hospital for investigation of jaundice. He had had a 'flu-like' illness one week before this. Jaundice had also occurred 3 and 5 years previously. There was no history of anaemia in the patient or his family.

On physical examination, he appeared ill, had a pyrexia of $30^{\circ} \mathrm{C}$, and had tender hepatomegaly. The spleen was not enlarged. A blood smear showed polychromasia but no spherocytes. Laboratory investigations included a haemoglobin value of $11.2 \mathrm{~g} / \mathrm{dl}$, a white blood count of $8.0 \times 10^{9} / 1$ with a normal differential, a reticulocyte count of $6.0 \%$, and platelets $200 \times 10^{9} / 1$. The total serum bilirubin was $41.0 \mu \mathrm{mol} / 1$ and the lactic dehydrogenase was greater than $600 \mathrm{IU} / \mathrm{l}$. The AST (aspartate aminoReceived for publication 10 August 1979 transaminase) was $93 \mathrm{IU} / 1$ (normal 7.0 to $40 \mathrm{IU} / \mathrm{l}$ ) and alkaline phosphatase was normal. The hepatitis associated antigen was negative. Chest $x$-ray showed irregular shadowing in the left mid-zone. The Coombs antiglobulin test was negative and the serum haptoglobins were zero. The osmotic fragility was normal and Heinz bodies were not detected. The autohaemolysis test showed $1.87 \%$ haemolysis after 48 hours and this was not fully corrected by addition of glucose $(1.4 \%)$. Urinary haemosiderin was negative and the ascorbate cyanide screening test was strongly positive.

After one week in hospital the patient's fever abated and his chest $x$-ray cleared. His steady state haemoglobin since discharge is $13.0 \mathrm{~g} / \mathrm{dl}$ with a reticulocyte count of $4 \%$.

The laboratory data during and after the patient's illness indicated a mild haemolytic state (persistent reticulocytosis). The ascorbate cyanide test was positive and this indicated a defect in the red cell hexose monophosphate shunt. The most likely cause of this defect was considered to be G6PD deficiency.

\section{Methods}

G6PD purification, determination of enzyme activity, starch gel electrophoresis, and kinetic studies (heat stability, Michaelis constant) were performed according to the methods described by the World 
Health Organization..$^{2}$ The partially purified enzyme preparations were stored at $4^{\circ} \mathrm{C}$ and used within 48 hours. All spectrophotometric assays were made on a Gilford Model 240 with Beckmann DU Monochromater. One unit of G6PD was that amount of enzyme needed to reduce $1 \mu \mathrm{mol}$ NADP per minute at $25^{\circ} \mathrm{C}$. Red cells were assayed for 6-phosphogluconate dehydrogenase by the method of Beutler. ${ }^{3}$

Control or normal G6PD was purified from red cells of laboratory staff in the manner referred to above and is designated Type $B$.

\section{Results}

\section{G6PD ACTIVITY}

Red cell G6PD activity in the proband was less than $10 \%$ of normal $(6 \cdot 1 \pm 2 \cdot 7 \%)$.

\section{ELECTROPHORESIS}

On starch gel the partially purified G6PD from the proband migrated to a similar position to the normal B (100\%).

\section{KINETIC CHARACTERISTICS}

The Michaelis constant for glucose-6-phosphate of the partially purified enzyme of the proband was within normal limits, $66 \mu \mathrm{mol} / \mathrm{l}$. Similarly, the Michaelis constant for NADP was $2.79 \pm 0.12$ $\mu \mathrm{mol} / \mathrm{l}$, the normal (B) being 2.9 to $4.4 \mu \mathrm{mol} / \mathrm{l}$. Utilisation of the substrate analogue 2-deoxyglucose6-phosphate was, however, consistently markedly increased, $26 \pm 2.0 \%$ of that of glucose-6-phosphate as shown in table 1 .

\section{pH EFFECT}

The effect of $\mathrm{pH}$ on the enzyme activity of the mutant G6PD was found to be similar to that of the normal B enzyme with a $\mathrm{pH}$ optimum at $\mathrm{pH} \mathrm{8 \cdot 0.}$

\section{STABILITY}

Partially purified mutant and control enzymes were heated at various temperatures until a temperature was found which caused a loss of about $20 \%$ of the activity in 20 minutes. Activity loss was too rapid

TABLE 1 2-deoxyglucose-6-phosphate (2dG6P) utilisation

\begin{tabular}{|c|c|c|c|}
\hline Sample & $\begin{array}{l}\text { Substrate } \\
(6 \mathrm{mmol} / \mathrm{l})\end{array}$ & $\begin{array}{l}\text { Activity } \\
\left(A_{340} / \min \times 10^{2}\right)\end{array}$ & $\begin{array}{l}\text { Utilisation } \\
(\%)\end{array}$ \\
\hline $\begin{array}{l}\text { Control } \\
\text { Control } \\
\text { Mutant } \\
\text { Mutant } \\
\text { Mutant } \\
\text { Control } 1: 10 \text { dilution } \\
\text { Control } 1: 10 \text { dilution } \\
\text { Mutant } \\
\text { Mutant } \\
\text { Mutant } \\
\text { Mutant }\end{array}$ & 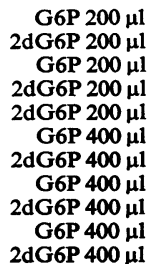 & $\begin{array}{l}3.4 \\
0.04 \\
0.11 \\
0.03 \\
0.025 \\
0.5 \\
0.01 \\
0.17 \\
0.05 \\
0.1 \\
0.025\end{array}$ & $\begin{array}{r}1 \cdot 2 \\
27 \cdot 3 \\
23 \cdot 0 \\
2 \cdot 0 \\
29 \cdot 4 \\
25 \cdot 0\end{array}$ \\
\hline
\end{tabular}

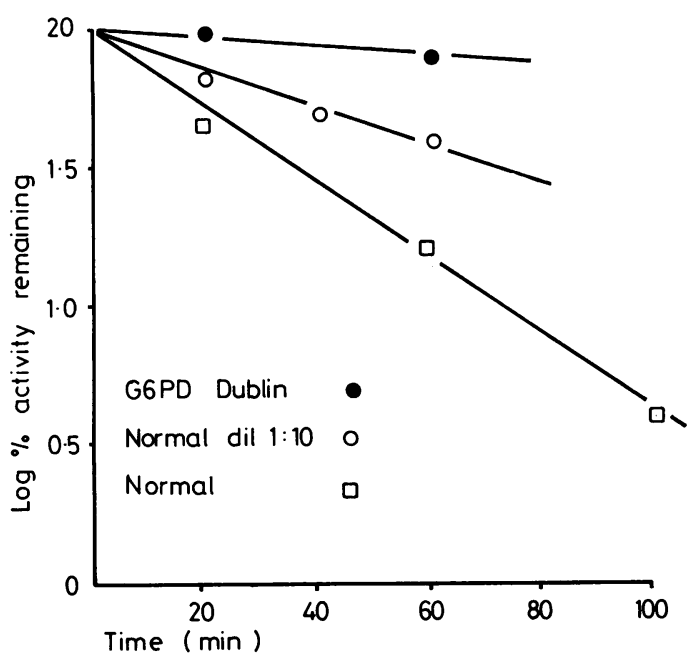

FIGURE Log percentage of initial activity of G6PD with time at $44^{\circ} \mathrm{C}$.

to be followed above $50^{\circ} \mathrm{C}$ in the case of the mutant ${ }_{0}^{\circ}$ enzyme. However, at $44^{\circ} \mathrm{C}$ the mutant G6PD was found to be relatively heat stable. The rates of inactivation in the case of the control, diluted control, and mutant enzyme are shown in the figure.

The mutant enzyme was highly unstable in a crude $\stackrel{0}{\frac{D}{D}}$ haemolysate and lost its activity within a few hours. On freezing and thawing the haemolysate, loss in $\overrightarrow{\overrightarrow{0}}$ activity was almost instantaneous. When mixed 3 with haemolysates from the deficient subject the activity of normal G6PD was not affected. Normal and mutant enzyme, partially purified, remained stable for 3 months when stored at $4^{\circ} \mathrm{C}$. The redo cell 6-phosphogluconate dehydrogenase (6PGADH) activity was within normal limits.

\section{Discussion}

It is now established ${ }^{4}$ that G6PD deficiency is by far $>$ the most common enzyme abnormality in man. In two of the major clinical groups, the 'Mediterranean' N and 'Negro' types, haemolytic anaemia occurs only' when the patient is subjected to an oxidant stress, such as oxidant drugs, infections, or in the case of $\omega$ the 'Mediterranean' type, fava beans. In the socalled 'sporadic' type, a chronic haemolytic stateo may exist in the absence of any oxidant stress and $\Phi$ this is referred to as chronic non-spherocytic ${ }^{?}$ haemolytic anaemia (CNSHA). ${ }^{5}$

In the patient reported above, the activity of G6PD was abnormally low. Further studies showed $\stackrel{\mathbb{P}}{\mathbb{P}}$ it to be different from normal G6PD and from $\stackrel{\square}{\square}$ other variants previously described. In table 2 , the 
TABLE 2 Comparison of the properties of the normal and mutant G6PD

\begin{tabular}{|c|c|c|c|c|c|c|c|}
\hline Property & $\begin{array}{l}\text { Normal enzyme } \\
(B)\end{array}$ & $\begin{array}{l}\text { Mutant enzyme } \\
\text { G6PD Dublin }\end{array}$ & $\begin{array}{l}\text { Mediter- } \\
\text { ranean }\end{array}$ & Englewood & Hamburg & Bagdad & Hillbron \\
\hline $\begin{array}{l}\text { Activity in red blood cell } \\
\text { haemolysate (\%) } \\
\text { 6PGADH activity in RBC }\end{array}$ & 100 & 10 & $0-7$ & 0.5 & & $0 \cdot 5$ & 12 \\
\hline $\begin{array}{l}\text { haemolysate }(\%) \\
\text { Electrophoretic mobility }\end{array}$ & 100 & 100 & 一 & 一 & 一 & 一 & 一 \\
\hline (\% of normal) & 100 & 100 & 100 & 100 & 100 & 100 & 100 \\
\hline $\begin{array}{l}\text { Km for glucose-6-phosphate }(\mu \mathrm{mol} / 1) \\
\text { Km for NADP }(\mu \mathrm{mol} / 1) \\
\text { Utilisation of } 2 \mathrm{dG6P}(\% \text { of G6P) }\end{array}$ & $\begin{array}{l}50-70 \\
2 \cdot 9-4 \cdot 4 \\
4\end{array}$ & $\begin{array}{l}66 \\
2 \cdot 79 \pm 0 \cdot 12 \\
26 \pm 3\end{array}$ & $\begin{array}{l}19-26 \\
1 \cdot 2-1 \cdot 6 \\
23-37\end{array}$ & $\begin{array}{r}56 \\
0 \cdot 5 \\
29 \cdot 6\end{array}$ & $\begin{array}{r}3 \cdot 8 \\
133\end{array}$ & $\begin{array}{l}70-77 \\
20-25 \\
45\end{array}$ & $\begin{array}{r}8 \cdot 5 \pm 0 \cdot 4 \\
1 \cdot 1 \pm 0 \cdot 02 \\
125\end{array}$ \\
\hline Stability in haemolysate & Stable & Unstable & - & - & - & - & - \\
\hline $\begin{array}{l}\text { Stability in partially purified enzyme } \\
\text { pH optimum } \\
\text { Heat stability }\end{array}$ & $\begin{array}{l}\text { Stable } \\
8-9 \\
\text { Normal }\end{array}$ & $\begin{array}{l}\text { Stable } \\
8 \cdot 0 \\
\text { Relatively } \\
\text { heat stable }\end{array}$ & $\begin{array}{l}\text { Biphasic } \\
\text { Low }\end{array}$ & $\begin{array}{l}\text { Biphasic } \\
\text { Labile }\end{array}$ & $\begin{array}{c}\text { 6.5 } \\
\text { Labile }\end{array}$ & $\begin{array}{l}\text { Biphasic } \\
\text { Low }\end{array}$ & $\begin{array}{l}\text { Biphasic } \\
\text { Normal }\end{array}$ \\
\hline
\end{tabular}

characteristics of the mutant G6PD are compared with the normal enzyme and with other variants known to have a utilisation of 2d6PG of 20 to $30 \%$ and to be associated with CNSHA. ${ }^{6}$ The comparison showed that the mutant is a new and distinct variant of G6PD.

The most distinctive features of the mutant enzyme are its low red cell activity (less than $10 \%$ of normal), the relative heat stability, and the marked increased in utilisation of 2 deoxy G6P, when compared with the normal G6PD. Studies of the heat stability of the enzyme at $44^{\circ} \mathrm{C}$ (figure) indicate that the mutant is more stable than normal G6PD. The increased activity with 2 deoxy G6P is very important in distinguishing the mutant from almost all the known variants of G6PD. It suggests that the mutant may be abnormal at the binding site in the active centre of the enzyme. Because the above properties of the mutant enzyme differ from all known variants of G6PD associated with CNSHA, we have called it G6PD Dublin.
We would like to thank Professor D G Weir for referring this patient for haematological evaluation.

\section{References}

1 Erslev AJ, Gabuzda TG. Pathophysiology of blood. Philadelphia: Saunders, 1975.

2 World Health Organization. Standardisation of procedures of the study of G-6-PD. WHO Tech Rep Ser 1967;366:1-53.

3 Beutler E. Red cell metabolism. A manual of biochemical methods. New York: Grune and Stratton, 1975.

4 Motulsky AG. Haemolysis in glucose-6-phosphate dehydrogenase deficiency. Fed Proc 1972;31:1286.

5 Williams WJ, Beutler E, Erslev AJ, Rundles RW. Hematology. New York: McGraw-Hill, 1977.

6 Beutler E, Yoshida A. Human glucose-6-phosphate dehydrogenase variants: a supplementary tabulation. Ann Hum Genet 1978 ;41 :347-53.

Requests for reprints to Dr S R McCann, Department of Clinical Haematology, St James's Hospital, PO Box 580, Dublin 8. 